\title{
HUMAN TRAFFICKING PREVENTION MEASURES AND WOMEN'S WELFARE PROMOTION IN RWANDA: A CASE OF NYARUGENGE DISTRICT, CITY OF KIGALI
}

\author{
Mr. Bosco Ntachobazi ${ }^{1 *}$, Dr. Paul Muiruri Munene ${ }^{2}$ \\ *1 International Relations and Diplomacy, School of Social sciences, Mount Kenya University, Kigali, Rwanda Email: \\ boscomugisha@gmail.com, \\ ${ }^{2}$ Lecturer, School of Social sciences, Mount Kenya University of Rwanda, Kigali Rwanda Email: \\ munenepaul1@gmail.com
}

*Corresponding Author: -

Email: boscomugisha@gmail.com

\begin{abstract}
: -
The purpose of this research was to analyze contribution of human trafficking measures prevention on women's welfare promotion in Rwanda: A case of Nyarugenge District, City of Kigali. The specific objectives were to ascertain the effect of awareness campaign, job creation and capacity building on women's welfare promotion in Nyarugenge District; Significance of the study will be to bring on lighter how these anti-human trafficking measures impact women in terms of women's welfare promotion and limitation of study were the language barrier and insufficient literature on the case of Rwanda. Scope of the study geographically covered Nyarugenge District, one of the districts that make up Kigali city. In a concise form, the study used a mixed research paradigm. It implies that both quantitative and qualitative approaches were adopted using a descriptive method. A sample size of 338 respondents was drawn from 2180 women beneficiaries of UN Women support in Nyarugenge District. The study used both stratified sampling techniques. Primary data was gathered using questionnaires and interview guide. Secondary data was gathered by the existing literature available in reports, published and unpublished books, electronic sources and journals. The study used descriptive and inferential statistics. In descriptive statistics, mean and standard deviation were used while in inferential statistics correlation and regression analysis was used. Results of the first objective show a significant correlation between stakeholders and target audiences and sales increase $(r=0.119 *, p=0.048)$, campaign tactics and techniques were positive correlated with income $(r=0.121, p=0.044)$ and ownership to properties $(r=0.102, p=0.091)$. There are positive and significant correlations between campaign tactics and techniques and income ( $r=0.119 *$, $p=0.048)$. Results on correlation between building and framing a campaign alliance and dependent variables, there were significant correlation between building and framing a campaign alliance and income $(r=.121 * *, p$ value $=0.044)$, building and framing a campaign alliance and ownership to properties ( $r=102, P$ value 0.091). Results to the second objective reveal significant correlations between business plan and income $\left(r=0.215^{*}, p=0.048\right)$, business plan and nutrition $(0.512 *, p=0.036)$. For entrepreneurship skills and nutrition $(r=0.931 * *, p=0.000)$, and ownership to properties $\left(r=0.680^{*}, p=.003\right)$ were positively correlated. Results to the third objective show significant positive correlations were found between agriculture and income ( $r=.167 *, p=.078)$, ownership to properties ( $r=.393 *$, $p=.000)$, and nutrition $\left(r=.560^{*}, p=.056\right)$. Significant positive correlations were found between tailoring activities and income level $(r=.032 *, p=.741)$, ownership to properties $\left(r=.058^{*}, p=.549\right)$ and tailoring activities and nutrition status $\left(r=-0.041^{*}, p=.669\right)$. However, a significant relation was found between outsourced companies in different services and nutrition status $\left(r=-0.443^{*}, p=.0 .075\right)$. The study recommends designing effective policies, establishing women's carrier orientation desks, the need to scale up in periodical campaign to ensure anti-human trafficking measures, help citizen in understanding that awareness in fighting human trafficking, discuss on the women and girls rights.
\end{abstract}

Keywords: - Anti-Human Trafficking Measures, Women's Welfare Promotion, Rwanda

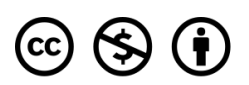




\subsection{INTRODUCTION}

Globally, women were under the domination, discrimination and dispersion of men and considered as subordinate to them (Collingwood, 2016). Women were frustrated when considered as sex-objects in female dominated society. In Sweden, Norway, Finland, Denmark and Canada, mothers are involved in preparing their daughters to undertake the role of motherhood participating in domestic affairs (Kabeer, 2011). As a result, girls learn that the kitchen the house and children are their domain. When the girl becomes adult, she is intended to establish and prepared food, fetch water, and look for firewood, pond maize and raising children (Mansuri \& Rao, 2013).

The historical background of human trafficking indicated that in $19^{\text {th }}$ century more than 4 million of person mainly female and children were traded from Africa (Ngwe \& Elechi, 2012). Rahman (2012) asserted that 31.6 million USD was gotten from women trafficking and illegal job. As a result, more than 27 million persons encountered human trafficking of various types and 97 were females violated in Africa. In African communities like Ghana,

Mali, Uganda, Cameroon, DRC think that the technological development and job market were the greatest impediments in combating human trafficking. People involved in human trafficking were facilitated by technological development and globalization (Ghiggi, et al, 2009).

Barner et al., (2014) argued that inequality between developed and developing countries are the pertinent element contributing to human trafficking. The globalization enables developed countries to exploit people from developing countries. Developed countries are stimulated by adequate and suitable business cooperation. Less developed countries generate raw resources that are supplied at low cost to the developed countries in order to process them and purchase them at greater cost to the less developed countries. This is the reason behind the division between advanced and less developed countries. Inequality between countries was determined in the context of revenue, resources, job, and accessibility to skills, political affairs, health services, social status and security. The inequality initiated in principles between developed and developing countries that was an attraction to impact the developing countries in term of human trafficking. The people involving in human trafficking utilize technology did not respect legal framework and they focus on fault promotional strategies on job websites for luring victims into the setup (Barner et al., 2014).

Previous studies evidenced that indicators of preventing human trafficking are education, capacity building, high cooperation, adequate awareness campaign and creating job to eliminate the problem of unemployment (RNP, 2015). Accroding to Dodo et al. (2012) assets that human trafficking was stimulated by lack of skills, lack of education, low standard of living conditions and disputes between families. Therefore, persons target them for mistreatment when they were unemployed. In addition, Florence and Shu-Acquaye (2013) reiterate the existence of restriction of understanding in as far as the issue of human trafficking. More to that, anti-human trafficking in place was not adopted to its significance. Moreover, the ability to enforce law by police and other public institutions such as immigration and migration expects to the increased for dealing with the crime of human trafficking adequately (Florence \& ShuAcquaye, 2013).

Binagwaho (2013), combating and following up human trafficking was a problem in Rwanda for enforcing law with duties to combat human trafficking respond to it when accessed information related to human trafficking. Answer to human trafficking appears when the survivors echo a fear, threat and menace (RNP, 2015). Based on a report by the United States Department (2013), Rwanda was proposed to create a coordination framework to connect all agencies involved in preventing human trafficking because it did not have coordination mechanism among ministries to manage all agencies that are responsible of the human trafficking and this affect the management and collaboration in the context of anti-trafficking mechanism and functions. The availability of financial, material and human resources necessitate being more adequate and suitable to assume all responsibilities that are responsible for combating human trafficking. In this regards, these were not sufficient and effective in Rwandan context (US Department of State, 2013). More police need training and equipment's are required (US State Department, 2013).

According to Abbot et al., (2015), it was felt that cultural practices continue to constrain female welfare. Girls and women were deprived their rights that improve their wellbeing. In Rwanda, land is small and did not give important option and therefore, persons went in cities to do prostitutions (Gasana et al., 2015). The equality between male and female os affected by social norms, traditions and cultural practices, discrimination, lack of educational qualification and self-assurance that emanate from inequality of them in the society (USAID, 2015). Ashiimwe (2014) evidenced that female between 16 and 40 years were suffering from human trafficking out of Rwanda. They were at all times from ignorance and poor living conditions and as they fight for obtaining the poor wellbeing by traveling where there were financial relations.

\subsection{Problem statement}

The growing problem around which this study turns consists on how to promote women's welfare. Kwibuka, (2016) argued that 74 women have been trafficked between 2015 and 2016. Despite initiative and measures adopted by the government of Rwanda, human trafficking persists and continue to deteriorate women's rights (Karuhanga, 2015). In fact, women suffer from ignorance that is, lack of access to education and awareness, sexual and domestic violence, living in male dominated society, undesired pregnancies, injustice, lack of access to properties and suffering from permanent trauma and depression (IOM,2010).

In order to promote women's welfare, anti- human trafficking measures are pointed out to play a significant role. Previous studies focused on the role of cooperation among neighboring countries (Wafula, 2011), awareness 
campaign on the crime of human trafficking (Ngwe \& Elechi, 2012), reliable data (Abbot, 2015), elimination of porous borders (Wafula, 2011), legal framework (Bishumba, 2017). Previous studies focused on policies and programs adopted to stimulate women's high political representation (Randell \& McCloskey, 2014), or economic women's empowerment (Burnet, 2011). But they did not tackle the crucial women's issues. These studies used qualitative approaches with small sample size. They did not also consider the role that employment creation, women empowerment, capacity building and raising awareness among community members would as human trafficking preventive measures would play in promoting women's welfare.

Empirical investigations in this regards, are thus worth undertaking in Rwanda specifically in Nyarugenge district. All the above considerations led the researcher to the study's problem consisting in knowing how an anti-human trafficking program/measures play a role in promoting women's welfare in Rwanda where a UN Women was undertaken as a case study in Nyarugenge District. The general objective of the present study is to analyze contribution of anti-human trafficking measures on women's welfare promotion in Rwanda: A case of Nyarugenge Distrcit, City of Kigali.

\subsection{Objective of the Study}

\subsubsection{General Objective}

The general objective of the present study is to analyze contribution of anti-human trafficking measures on women's welfare promotion in Rwanda: A case of Nyarugenge Distrcit, City of Kigali.

\subsubsection{Specific Objectives}

(i) To ascertain the effect of awareness campaign on women's welfare promotion in Nyarugenge Distrcit.

(ii) To examine the effect of capacity building on women's welfare promotion in Nyarugenge Distrcit.

(iii) To assess the effect of job creation on women's welfare promotion in Nyarugenge Distrcit.

\subsection{Literature review}

\subsection{Empirical literature}

A research conducted by Ballington, et al.,(2012), on the effects of trainings and capacity development on promotion of women's economic rights in developing countries. The study reveal that in less developed and African countries, poor female and girls with low income, low standard of living, low investment spirit in skilled personnel and higher challenges on labor market accessibility in contrast with their counterpart in advanced and western countries.

Kwibuka, (2016) studied Rwanda: MPs hold dialogue on human trafficking. The study found that 74 women suffered from human trafficking in Rwanda between 2015 and 2016. IOM (2012) argued that preventing human trafficking is a complex issue in Rwanda owing to lack of knowledge towards the reality of job market as well as they were attracted by the hope of finding job in foreign countries (Shelley, 2010). However, the republic of Rwanda has programs adopted to prevent and fight its citizens against human trafficking in cooperation with the other countries.

Wafula (2011) conducted a study on Border management and security in Africa. The study found that in order to promote women's welfare, anti- human trafficking measures are pointed out to play a significant role. The studies focused on the role of cooperation among neighboring countries. A research undertaken by Field, et al., (2010) on the role of awareness campaign on promoting women's welfare in South Africa. The research found out that awareness campaign could enable people so that those who are not included have the confidence and skills to take part in decision making process, and claim their rights to do so. Holmes and Jones (2010) reiterate that collaboration with other agencies moved from immediate fund schedule with greatest of its executing partners to re-fund mediate plan. Hypher (2011) specified the role of direct support for job creation in promoting women's welfare. The social protection agencies facilitate economic development for vulnerable groups. It is confirmed that adding to its security net duties, it improves the revenue of poor families either by assuring the low revenue or job or through insurance and aids.

Krafft (2015) study on Increasing women's skills and awareness in rural area of Egypt: women and education. The study used desk research method Journals and books. The study found out that stakeholders must provide trainings to women beneficiaries of their project. Krafft argued that trainings refers to educating, improving in oneself and knowledge that is associated to special important capabilities

Ballington (2012) study on empowering women for political parties: a guide book to promote political participation. The evaluation methods used were mainly quantitative Fieldwork lasted eight weeks. The study found failure to recognize the trainings as women' welfare promoting tools. The study establish what to be done in organization to promote women's awareness of their welfare. According to Beath, et al., (2010) studied Randomized Impact Evaluation of Phase II of Afghanistan's National Solidarity Program (NSP) - Estimates of Interim Program Impact from First Follow-Up Survey. The study found that knowledge has been observed as pertinent for production increase, job opportunities and income generating activities, improving nutrition status and advancing the sustainability of women socioeconomic development and living conditions. In this vein, previous studies focused on the performance of these anti-human trafficking policies.

The existing literature demonstrated that capacity building had a clear correlation between job and female emancipation (Booth, 2012). Despite previous researches could out any information for female comparing with men (Devarajan, et al., 2011). Disparities between men and women in levels of education completion and accessibility to business marketplace could limit female capacity to gain from tangible assistance (Riza, 2013). Owing to these disparity, female often did not have business management skills and are less given on investment chances in comparison to female (Ashraf, et al., 2010).

Johnson, et al., (2013) studied the Gendered Impacts of Agricultural Asset Transfer Projects: Lessons from the Manica 
Smallholder Dairy Development Program The study found that taking into consideration, social protection plans usually aimed women- head of their families and term women to obtain the transfer, pertinence of these places for facilitating women's economic empowerment is crucial. The study argues that social protection plans may not attain women's empowerment in separation. Simply, when they possess gender equality targets, were given in ways that confirm female involvement and were managed with gender sensitive development supports and services to social protection plan as causes of economic empowerment for women.

Holmes \& Jones, (2013) study on Social protection and gender life cycle model. The used Inferential statistics and a small sample size A well-managed social protection programs are designed to enhance female' accessibility to land, education and improve their involvement in working institutions and these lead to socio-economic development and women's emancipation. The findings show the effects of social protection services offered to women in economic context. The research renders it via a systematic revision of information on social protection plan, evaluating the degree to which their effects on women's welfare and when probable policies intend features that stimulate clear effects. There is lack of skills related to pertinent effects of common actions on female's authority and entities. These effects may be seen at more methodical in the future program assessment.

\subsection{Research Gap}

Previous studies have been carried out outside in Sweden, Finland, Denmark, Canada, Ghana and South Africa. No studies, has been conducted in Rwanda, then it would be in Nyarugenge District. Related studies done by the researchers focused their attention on how women should be submissive and how they were seen within the society but did not show how women's welfare should be promoted and enforced within the society and cultural context. Few of researches had emphasized on the effects of capacity building and training in promoting women's welfare (Krafft, 2015). However, none of previous studies had shown clear association between trainings of women, advocacy for women, collaboration with other agencies and direct support provided to women beneficiaries of UN Women and the promotion of women's welfare. It is the first gap that this research seeks to assess. There are also many reports about women's rights but researchers do not focus on their efficiency in promoting women's welfare in Rwanda a case of Nyarugenge District.

Table 2.1: A Summary of Empirical Literature Review

\begin{tabular}{|c|c|c|c|c|}
\hline Author\& Year & Title & Methodology & Results & Knowledge Gap \\
\hline Krafft (2015). & \begin{tabular}{|c|} 
Increasing women's \\
skills and awareness \\
in rural area of Egypt: \\
women and \\
education.
\end{tabular} & $\begin{array}{l}\text { Study used desk } \\
\text { research method } \\
\text { Journals and } \\
\text { books }\end{array}$ & $\begin{array}{c}\text { The study found out that } \\
\text { stakeholders must provide } \\
\text { trainings to women } \\
\text { beneficiaries of their project }\end{array}$ & $\begin{array}{l}\text { Study should be done on the } \\
\text { nature and contents of } \\
\text { trainings offered to women } \\
\text { in order to promote their } \\
\text { welfare }\end{array}$ \\
\hline $\begin{array}{l}\text { Ballington } \\
(2012)\end{array}$ & $\begin{array}{c}\text { The empowering } \\
\text { women for political } \\
\text { parties: a guide book } \\
\text { to promote political } \\
\text { participation }\end{array}$ & $\begin{array}{l}\text { The evaluation } \\
\text { methods used } \\
\text { were mainly } \\
\text { quantitative } \\
\text { Fieldwork lasted } \\
\text { eight weeks }\end{array}$ & $\begin{array}{c}\text { Failure to recognize the } \\
\text { trainings as women' } \\
\text { welfare } \\
\text { promoting tools }\end{array}$ & $\begin{array}{c}\text { Establish what to be done in } \\
\text { organization to promote } \\
\text { women's awareness of their } \\
\text { welfare }\end{array}$ \\
\hline $\begin{array}{c}\text { Amuzu, Jones } \\
\text { and Pereznieto } \\
(2010)\end{array}$ & $\begin{array}{c}\text { gender risks, poverty } \\
\text { and vulnerable in } \\
\text { Ghana }\end{array}$ & $\begin{array}{l}\text { The correlation } \\
\text { and regression } \\
\text { analysis }\end{array}$ & $\begin{array}{l}\text { Results demonstrated the } \\
\text { role of civil society and } \\
\text { state prone ship in } \\
\text { eliminating gender } \\
\text { inequality }\end{array}$ & $\begin{array}{c}\text { The study should establish } \\
\text { the influence of job creation } \\
\text { in promoting women's } \\
\text { welfare }\end{array}$ \\
\hline $\begin{array}{l}\text { Holmes and } \\
\text { Slater (2012) }\end{array}$ & $\begin{array}{c}\text { Social protection and } \\
\text { gender life cycle } \\
\text { model }\end{array}$ & $\begin{array}{c}\text { Inferential } \\
\text { statistics } \\
\text { She used a small } \\
\text { sample size }\end{array}$ & $\begin{array}{l}\text { The findings show the } \\
\text { effects of social protection } \\
\text { services offered to women } \\
\text { in economic context }\end{array}$ & $\begin{array}{l}\text { The study should assess the } \\
\text { influence of social } \\
\text { protection support in gender } \\
\text { mainstreaming and women } \\
\text { welfare direction }\end{array}$ \\
\hline Hypher (2011) & \begin{tabular}{|} 
Impact of Cash \\
Transfers on \\
Children.
\end{tabular} & $\begin{array}{c}\text { Descriptive and } \\
\text { Correlation }\end{array}$ & $\begin{array}{l}\text { There was a positive } \\
\text { correlation between cash } \\
\text { transfers and promotion of } \\
\text { women's welfare }\end{array}$ & $\begin{array}{l}\text { The study should examine } \\
\text { the impacts of multiple } \\
\text { components of direct } \\
\text { support in promoting } \\
\text { women's welfare }\end{array}$ \\
\hline
\end{tabular}

Source: Empirical Literature Review

Most of the studies revised were carried out outside of Rwanda, therefore, establishing a contextual gap. These studies are undertaken in Sweden, Norway, India, Ghana, Egypt, and Bangladesh (Krafft, 2015; Ballington, 2012; Amuzu, et al., 2010; Holmes and Slater, 2012; and Hypher, 2011). Therefore, no study had focused on effects of trainings provided to women, awareness campaign or advocacy done for women, and direct support provided to women in order 
to create job and promote their welfare in the context of women beneficiaries. Furthermore, there is the context and literature gap that this research seeks to fill.

These studies did not explain the contribution made by anti-human trafficking strategies used by UN-Women in ensuring the promotion of women's welfare basing on their key rights promotional indicators such as an improved nutritional status, income level and accessibility to properties (exposure to opportunities, female access to property rights. Thus, the study attempted to fill the gap, while it focuses on Nyarugenge District.

\subsection{Methods and materials}

This study adopted descriptive research design was used and employed coefficient of correlation to measure effect size$r$ for each objective. Alvi (2016) defines a descriptive research design as the process of collecting and analyzing data for describing specific portent in the present of affair or associations among various elements. The study applied a descriptive that is intended at assessing impact of an independent variable to dependent variables. In a concise form, the researcher used a mixed research paradigm. It implied that both quantitative and qualitative approaches were adopted The target population of the present study consists of women supported by UN Women agency in Nyarugenge District, located in the City of Kigali-Rwanda. National Institute of Statistics of Rwanda (2017), argues that Nyarugenge district comprises of 136,429 women and 148,132 men. The UN Women Rwanda reiterates that it supports 2180 women in Nyarugenge District and 12 policemen are involved in UN Women activities towards, the fight against human trafficking. A sample size of 339 women beneficiaries of UN Women activities in Nyarugenge District-Rwanda were chosen using Yamane formula.

$$
n=\frac{N}{1+N^{*}(e) 2}
$$

Therefore, as mentioned formula is presented in the following way: $\mathrm{n}=$ represent the sample size; $\mathrm{N}=$ represent the total target population; $\mathrm{e}=5 \%(0.05)$ represent the sampling/marginal error. The study was carried out on 339 Women in Nyarugenge district who benefit from UN Women's welfare program. The area has been chosen because it has the targeted population and the benefits got from UN women are similar to those of other beneficiaries all over the country. The study adopted both stratified sampling and simple random sampling technique. Stratified sampling technique is a type of sampling approach in which the total population is divided into smaller group to achieve the sampling process To confirm reliability, the tool was assessed on 39 women beneficiaries of UN Women activities from Kamonyi district which was not among the selected sample that is in Nyarugenge Distrcit. In fact, reliability was denoted by its consistency after a pilot study. A pre-test was carried out for questionnaire after one week on the similar people and whether findings reach 0.05 and then the tool was qualified as reliable (Amin, 2005). The pre-test will help the researcher to check whether the variable that was collected was easy to proceed and to analyse.

For validity of the study, content validity was confirmed by using an effect term like expert validity that assess independent and dependent variable. In order to validate the instruments, the validity test was ascertained by experts in gender studies after discussion with the supervisor. The reliability range starting from 0.50 to 0.60 was enough for exploratory design. However, reliability ranging from 0.70 and above was mostly adequate and accepted and over 0.80 was good enough. The validity of questionnaire was achieved through consultation with the supervisor based research objectives. Data was analyzed using a descriptive and correlational statistics establishing the mean and standard deviation of the collected information using a Statistical Package for Social Sciences (SPSS) version 26.0. The following regression equation was applied.

Where $\quad \mathrm{Y}=$ Women's welfare, $\mathrm{bo}=$ constant,

$$
y=\beta 0+\beta_{1} X_{1}+\beta_{2} X_{2}+\beta_{3} X_{3}+\varepsilon
$$

$\mathrm{X} 1=$ Awareness campaign, $\mathrm{X} 2=$ Capacity building, $\mathrm{X} 3=\mathrm{J}$ ob creation.

\subsection{Research Findings}

4.1 Effect of awareness Campaign on Women's Welfare Promotion in Nyarugenge Distrcit Table 4. 1: Awareness Campaign

\begin{tabular}{lllllllll}
\hline & \multicolumn{7}{c}{ Strongly Disagree DisagreeNot SureAgreeStrongly Agree } \\
Awareness Campaign & $\%$ & $\%$ & $\%$ & $\%$ & $\%$ & MeanSd \\
\hline Setting the goals, outcomes and timing & 4.1 & 18.9 & 18.6 & 36.1 & 22.2 & 3.53 & 1.5 \\
Stakeholders and target audiences & 8.6 & 21.0 & 24.3 & 28.7 & 17.5 & 3.25 & 1.21 \\
Campaign tactics and techniques & 8.0 & 22.8 & 23.4 & 29.6 & 16.3 & 3.23 & 1.20 \\
Building and framing a campaign alliancell.2 & 9.5 & 24.0 & 30.5 & 24.9 & 3.48 & 1.27 \\
\hline
\end{tabular}

Source: Primary Data, 2021

Findings in Table 4.1 that shows majority $(36.1 \%)$ of respondents strongly agree that setting the goals, outcomes and timing was among other contents of awareness campaign, given to women in Nyarugenge District. Moreover, $28.7 \%$ respondents agreed with the statement that stakeholders and target audiences was done. However, campaign tactics and 
techniques given to respondents where $29.6 \%$ respondents strongly agreed with the statement. Finally, building and framing a campaign alliance was strongly agreed as a content of building and framing a campaign alliance. The researcher discovered that after having an interview with UN Women staff in order to know what activities related to awareness campaign realized by awareness.

Table 4. 2: Correlation Analysis between Awareness Campaign and Women Welfare.

\begin{tabular}{llcc}
\hline & & Awareness Campaign & Women Welfare \\
\hline Awareness & Pearson Correlation & & $.683^{*}$ \\
& Sign.(2-tailed) & .008 & .004 \\
& $\mathrm{~N}$ & 338 & 338 \\
\multirow{2}{*}{ Women Welfare } & Pearson Correlation & .005 & .007 \\
& Sig.(2-tailed) & 009 & .010 \\
& $\mathrm{~N}$ & 338 & 338 \\
\hline
\end{tabular}

Source: Primary Data, 2021

Findings presented in Table 4.2 reveal correlation between variables. Awareness Campaign and Women Welfare there is strong a positive insignificant correlation between Awareness Campaign and Women Welfare $(r=0.683, p=0.004)$

Table 4.3: Univariate analysis of Capacity Building and Women Welfare

\begin{tabular}{llllll}
\hline & \multicolumn{2}{l}{ Unstandardized Coefficients } & \multicolumn{2}{l}{ Standardized Coefficients } & \\
Model & B & Std. Error & Beta & t & Sig. \\
\hline (Constant) & 2.788 & .422 & & 6.607 & .000 \\
Capacity Building & .042 & .060 & .042 & .701 & .484 \\
\hline
\end{tabular}

Source: Primary Data, 2021

The univariate analysis of $y=\beta 0+\beta_{1} X_{1}+\varepsilon$ becomes Women's welfare $=2.788+0.42$ Capacity Building. This means that when Capacity Building is hold constant Women's welfare is 2.788. Unit of Capacity Building will lead to increase of Women's welfare by a factor of 0.42 with $\mathrm{P}$ value of 0.484

An interview with UN Women representative argues "the awareness campaign is very important in term of improving women income, ownership to properties and nutrition status". The results were relevant in comparison with concluding remarks of A research conducted by Ballington, et al.(2012), on the effects of trainings and capacity development on the promotion of women's economic position in developing countries. The study reveal that in developing countries, women suffer from lower levels of economic and social empowerment, poorer investment in human capital and greater restrictions on access to labour markets in comparison to their peers in developed countries.

4.2 Effect of Capacity Building on Women's Welfare Promotion In Nyarugenge Distrcit. Table 4. 4: Capacity building Offered to Beneficiaries by UN-Women in Rwanda

\begin{tabular}{|c|c|c|c|c|c|c|c|}
\hline \multirow{3}{*}{$\frac{\text { Advocacy }}{\text { Business Plan }}$} & \multicolumn{2}{|c|}{ Strongly DisagreeDisagree } & \multirow{2}{*}{$\begin{array}{l}\text { Not Sure } \\
\%\end{array}$} & \multirow{2}{*}{$\begin{array}{l}\text { Agree } \\
\%\end{array}$} & \multicolumn{3}{|c|}{ Strongly Agree } \\
\hline & $\%$ & $\%$ & & & $\%$ & Mear & $\mathrm{Sd}$ \\
\hline & 5.9 & 13.0 & 18.3 & 50.3 & 12.4 & 3.50 & 1.05 \\
\hline Entrepreneurship skills & 6.2 & 20.4 & 23.4 & 26.9 & 23.1 & 3.40 & 1.21 \\
\hline Project management & 5.9 & 17.2 & 18.6 & 34.9 & 23.4 & 3.52 & 1.19 \\
\hline \multicolumn{2}{|c|}{ Adequate Loan Utilization 6.5} & 20.1 & 24.6 & 29.6 & 19.2 & 3.34 & 1.18 \\
\hline
\end{tabular}

Source: Primary data, 2021

Results presented in Table 4.4, provides information on types of effect of capacity building on women's welfare promotion in Nyarugenge Distrcit. Accordingly, 50.3 agreed that UN Women provided capacity building on business plan. Furthermore, $26.9 \%$ of respondents evidence and agree that UN women provided capacity building on entrepreneurship skills to women beneficiaries.

Moreover, $34.9 \%$ of respondents agreed with the statement that UN Women argue that all women beneficiaries were given trainings related to project management. Finally, 100 respondents agreed that the UN Women prepared training related to adequate loan utilization. 
From the interview contend that capacity building offered to beneficiaries by UN-Women in Rwanda is held for promoting women's welfare, but since it is done at high level institutions, the beneficiaries have less knowledge on how it is implemented. Results from the present study concur with the findings of Field, et al.( 2010). The scholar reiterate that although the government has attempted to advocate for women welfare through women friendly program, they are not enough for effective women's welfare promotion and awareness.

Table 4.5: Correlation Analysis between Capacity Building and Women Welfare Promotion in Nyarugenge District.

\begin{tabular}{llcc}
\hline & & Capacity Building & Women Welfare \\
\hline Capacity Building & Pearson Correlation Model & 1 & $0.680^{* *}$ \\
& Sign. (2-tailled) & 0.04 & 0.004 \\
& $\mathrm{~N}$ & 338 & 338 \\
\multirow{5}{*}{ Women Welfare } & Pearson Correlation Model & $0.680^{* *}$ & 1 \\
& Sign. (2-tailed) & 0.003 & 0.000 \\
& $\mathrm{~N}$ & 338 & 338 \\
\hline
\end{tabular}

Source: Primary Data, 2021

As indicated in Table 4.6 there are significant correlations found between Capacity Building and Women Welfare Promotion in Nyarugenge District.( $\mathrm{r}=00.680, \mathrm{p}=0.04)$, Correlations were statistically significant given that the $\mathrm{p}$ value was $<0.05$ suggesting that an Capacity Building and Women Welfare Promotion in Nyarugenge District has strong positive relation.

Table 4. 6: Univariate analysis of Awareness Campaign and Women Welfare

\begin{tabular}{|c|c|c|c|c|c|c|}
\hline \multirow{2}{*}{\multicolumn{2}{|c|}{ Model }} & \multicolumn{2}{|c|}{ Unstandardized Coefficients } & \multicolumn{2}{|c|}{$\begin{array}{l}\text { Standardized } \\
\text { Coefficients }\end{array}$} & \multirow[b]{2}{*}{ Sig. } \\
\hline & & B & Std. Error & Beta & $\mathbf{t}$ & \\
\hline \multirow[t]{2}{*}{1} & (Constant) & 2.883 & .416 & & 6.925 & .000 \\
\hline & $\begin{array}{l}\text { Awareness } \\
\text { Campaign }\end{array}$ & .126 & .056 & .129 & 2.142 & .033 \\
\hline
\end{tabular}

Source: Primary Data, 2021

The regression equation $y=\beta 0+\beta_{2} X_{2}+\varepsilon$ becomes Women's welfare $=2.883+0.56$ awareness campaign. This means that when Awareness Campaign is hold constant Women's welfare is 2.788.Unit of awareness campaign will lead to increase of Women's welfare by a factor of 0.42 with $\mathrm{P}$ value of 0.484

According to Beath, et al,. (2010), the on skills development was as seen as a key to improving rural productivity, employability and earning opportunities, enhancing food security and promoting sustainable rural development and livelihoods. However, the literature indicates mixed evidence for the success of these interventions

4.3 Effect of Job Creation on Women's Welfare Promotion in Nyarugenge District Table 4.7: Job Creation for Women's in Nyarugenge District

\begin{tabular}{lccccccc}
\hline & \multicolumn{7}{c}{ Strongly DisagreeDisagreeNot SureAgreeStrongly Agree } \\
Job Creation & $\%$ & $\%$ & $\%$ & $\%$ & $\%$ & & MeanSd \\
\hline Agriculture & 11.8 & 13.9 & 12.4 & 44.1 & 17.8 & 3.42 & 1.26 \\
Agribusiness activities & 4.1 & 12.4 & 22.8 & 39.3 & 21.3 & 3.61 & 1.07 \\
Tailoring activities & 8.3 & 11.8 & 17.5 & 37.3 & 25.1 & 3.59 & 1.21 \\
Outsourced companies in different services 11.8 & 17.5 & 37.3 & 11.8 & 19.4 & 3.32 & 1.32 \\
\hline
\end{tabular}

Source: Primary Data, 2021

Findings in Table 4.7 indicate that $44.1 \%$ of respondents agreed that UN women created job in agricultural sector. In addition, $39.3 \%$ of respondents indicated that the UN women cooperate with other partners in creating job in agribusiness sector for women beneficiaries in Nyarugenge District.

In the same vein, $37.3 \%$ of confirmed that UN Women cooperate strongly with tailoring activities for women beneficiaries in Nyarugenge District. Finally, the findings evidences that UN women tries to created job in outsourced companies in different services. This was confirmed by $33.4 \%$ of respondents who agree with the statement that UN women were in outsourced companies in different services. It has been concluded that respondents agree that UN Women facilitates job creation for women. 
Table 4.8: Correlations between Job Creation and Women's Welfare Promotion in Nyarugenge DistrictRwanda

\begin{tabular}{llll}
\hline & & Job Creation & $\begin{array}{l}\text { Women's } \\
\text { Promotion }\end{array}$ \\
\hline Job Creation & Pearson Correlation & 1 & $.393^{* *}$ \\
& Sig.(2-tailed) & .008 & .006 \\
& $\mathrm{~N}$ & 338 & 338 \\
Women's Welfare Promotion & Pearson Correlation & $.393^{* *}$ & 1 \\
& Sig. (2-tailed) & .002 & .008 \\
& $\mathrm{~N}$ & 338 & 338 \\
\hline
\end{tabular}

**. Correlation is significant at the 0.01 level (2-tailed).

Source: Primary Data, 2021

As indicated in Table 4.8, there was in significant positive correlations were found between Job Creation and Women's Welfare Promotion in Nyarugenge District-Rwanda ( $\mathrm{r}=.383, \mathrm{p}=.006)$. There was moderate correlation between Job Creation and Women's Welfare Promotion in Nyarugenge District-Rwanda.

Univariate analysis of Job Creation and Women Welfare Promotion

Table 4.9: Coefficients of Regression between Job Creation and Women Welfare Promotion

\begin{tabular}{|c|c|c|c|c|c|}
\hline \multirow[b]{2}{*}{ Model } & \multicolumn{2}{|c|}{ Unstandardized Coefficients } & \multirow{2}{*}{$\begin{array}{l}\text { Standardized Coefficients } \\
\text { Beta }\end{array}$} & \multirow[b]{2}{*}{$\mathbf{t}$} & \multirow[b]{2}{*}{ Sig. } \\
\hline & B & Stad. Error & & & \\
\hline (Constant) & 4.030 & .374 & & 10.779 & .000 \\
\hline Job Creation & .059 & .053 & 088 & 1.121 & .263 \\
\hline
\end{tabular}

\section{Source: Primary Data, 2021}

Regression equation $y=\beta 0+\beta_{3} X_{3}+\varepsilon$ becomes Women's welfare $=4.030+0.59$ Job Creation. This means that when Job Creation is hold constant Women's welfare is 4030.Unit of Job Creation will lead to increase of Women's welfare by a factor of 0.59 with $\mathrm{P}$ value of 0.263 .

According to Karlan and Valdivia (2011), the fulfilment of female's expectations via service delivery is very important and would give time for them to accomplish their prospective. Therefore, the supply of services happened in the challenges encountered by community, domestic and foreign legal frameworks and in term of social rules and values that mean female contribution (Jensen, 2012).

All activities undertaken by UN Women enhance women rights promotion. Each of these elements significantly promote women's welfare promotion when they were improved. Study findings did not contradict the results of the research carried out by (Corduneanu \& Masses, 2013). The interaction matrix table also demonstrated the relationship coefficient between pairs of variables. Results from this study concurs with the observation of Hypher (2011) who found that the use of training or women capacity building is very important in enabling women access to social justice and to job opportunities. This allows having awareness to occur while community involvement gives women a good opportunity to imitate with appropriate societal emancipation strategies like advocacy and affording direct support to vulnerable women in developed countries. Results did not contradict the study of Bandiera, et al. (2013) who found that the use of training for promoting women's rights awareness. Results from this research did not contradict with observations of Jones and Thi (2012) who carried out research on the role of direct support in promoting women awareness. The authors demonstrated that women's welfare recommend that provision of direct support and training can plays a significant role in promotion women's welfare. The present study, did not contradict with Randell and McCloskey (2014), despite the UN dedicated to gender empowerment across all its work, true promotion necessitates more than permitting women into international organizations, it may necessitate changing the structure and assumptions of the international order. In a pertinent acknowledgement of the effects of state inability on the conduct of non-state actors, the committee declares that the state's inaction with respect to these acts gives a form of stimulation and defecto permission and encourages non-state actors to dedicate acts impermissible under the convention with impunity (Amuzu, et ,.al,. 2010).

Generally, collection action are acts of mobilizing people around common or shared concerns. The action may be routine or sporadic, it may take place through an organization or government structure. It may be localized or transnational by focusing on articulation of rights, it may be induced from external or as is most of the case, it may evolve organically (Bandiera, et al., 2013). 
4.4 Inferential statistics Table:4.10: Model Summary

\begin{tabular}{ccccc}
\hline \multicolumn{5}{c}{ Model Summary } \\
\hline Model & $\mathrm{R}$ & R Square & Adjusted R Square & Std. Error of the Estimate \\
1 & $.732^{\mathrm{a}}$ & .693 & .639 & .145 \\
\hline
\end{tabular}

a. Predictors: (Constant), Awareness Campaign, Capacity Building Job Creation

Source: Primary data, 2021

The results on Table 4.10 showed that anti-human trafficking measures (Awareness Campaign, Capacity Building Job Creation ) had explanatory power on the change in women's welfare promotion as it accounted for $63.9 \%$ of its variability $(\mathrm{R}$ Square $=0.693$ ) hence the model is a good fit for the data. anti-human trafficking measures (Awareness Campaign ,Capacity Building Job Creation ) as a variable on its own implies a moderate positive relationship with change as it accounted for $63.9 \%$ of its variability $(\mathrm{R}$ Square $=0.693$

Table:4 11: Analysis of variance (ANOVA)

\begin{tabular}{cccccc}
\hline Mo & Sum of Squares & Df & Mean Square & F & Sig. \\
\hline Regression & 8.212 & 3 & 2.737 & 18.471 & $.002^{\mathrm{a}}$ \\
Residual & 45.198 & 335 & & .148 & \\
Total & 53.410 & 338 & & & \\
\hline
\end{tabular}

a. Predictors: (Constant), Awareness Campaign ,Capacity Building Job Creation

b. Dependent Variable: women's welfare promotion

Source: Primary data, 2021

From the above table, findings indicates.ANOVA Results Table 4.11 presents the analysis of variance of the study on anti-human trafficking measures (Awareness Campaign ,Capacity Building Job Creation on women's welfare promotion. The results reveal that a significant relationship exists between anti-human trafficking measures (Awareness Campaign ,Capacity Building Job Creation on women's welfare promotion with a p-value of 0.02 The P-value is less than 0.05 , thus indicating that the predictor variable explain the variation in the dependent variable, which is anti-human trafficking measures (Awareness Campaign ,Capacity Building Job Creation with F ratio (3, 335) was $18.471, p=0.02$ ). If significance value of $P$ was larger than 0.05 then the independent variables would not explain the variation in the dependent variable (Lakew \& Rao, 2009).

Table 4.12: Regression results

\begin{tabular}{|c|c|c|c|c|c|c|}
\hline \multirow[b]{2}{*}{ Model } & & \multicolumn{2}{|c|}{ Unstandardized Coefficients } & \multicolumn{2}{|l|}{$\begin{array}{l}\text { Standardized } \\
\text { Coefficients }\end{array}$} & \multirow[b]{2}{*}{ Sig. } \\
\hline & & $\mathrm{B}$ & Std. Error & Beta & $\mathrm{t}$ & \\
\hline \multirow[t]{4}{*}{1} & (Constant) & 7.779 & .422 & & 6.607 & .000 \\
\hline & Awareness Campaign & .143 & .064 & .134 & 2.239 & .026 \\
\hline & Capacity Building & .107 & .065 & .100 & 1.648 & .101 \\
\hline & Job Creation & .109 & .071 & .094 & 1.552 & .122 \\
\hline
\end{tabular}

a. Dependent Variable: Women Welfare

Source: Primary Data (2021)

The Regression equation $y=\beta_{0}+\beta_{1} X_{1}+\beta_{2} X_{2}+\beta_{3} X_{3}+\varepsilon$ becomes women welfare=7.779+ 0.143Awareness Campaign + 0.107Capacity Building+ 0.109 Job Creation. This means that when Job Creation is hold constant Awareness Campaign, Capacity Building, and Job Creation women welfare promotion will be 7.779 Unit of awareness Campaign will lead to increase of Women's welfare promotion by a factor of 0.143 with $\mathrm{P}$ value of 0.026 , Unit of Capacity Building will lead to increase of Women's welfare promotion by a factor of 0.107 with $\mathrm{P}$ value of.101 while Unit of Job Creation will lead to increase of Women's welfare promotion by a factor of 0.109 with $\mathrm{P}$ value of 0.122

\subsection{Summary}

Findings discovered that the kind of awareness campaign done towards women's welfare promotion include setting the goals, outcomes and timing, stakeholders and target audiences, campaign tactics and techniques and building and framing a campaign alliance. In this regard, majority $(36.1 \%)$ of respondents strongly agree that setting the goals, outcomes and timing was among other contents of awareness campaign, given to women in Nyarugenge District. Moreover, $28.7 \%$ respondents agreed with the statement that stakeholders and target audiences was done. However, campaign tactics and techniques given to respondents where $29.6 \%$ respondents strongly agreed with the statement. Finally, building and framing a campaign alliance was strongly agreed as a content of building and framing a campaign alliance. The researcher discovered that after having an interview with UN Women staff in order to know what activities related to awareness campaign realized by awareness. Findings presented in Table 4.3 reveal correlation between variables. Awareness Campaign and Women Welfare there is strong a positive insignificant correlation 
between Awareness Campaign and Women Welfare $(r=0.683$, $\mathrm{p}=0.004)$

Results felt that provides information on types of effect of capacity building on women's welfare promotion in Nyarugenge District. Accordingly, 50.3 agreed that UN Women provided capacity building on business plan. Furthermore, $26.9 \%$ of respondents evidence and agree that UN women provided capacity building on entrepreneurship skills to women beneficiaries. Moreover, $34.9 \%$ of respondents agreed with the statement that UN Women argue that all women beneficiaries were given trainings related to project management. Finally, respondents agreed that the UN Women prepared training related to adequate loan utilization. From the interview contend that ccapacity building offered to beneficiaries by UN-Women in Rwanda is held for promoting women's welfare, but since it is done at high level institutions, the beneficiaries have less knowledge on how it is implemented. As indicated in Table 4.6 there are significant correlations found between Capacity Building and Women Welfare Promotion in Nyarugenge District.(r=00.680, $\mathrm{p}=0.04)$,

Findings reiterate that $50.3 \%$ agreed that UN Women provided capacity building on business plan. Furthermore, 26.9\% of respondents evidence and agree that UN women provided capacity building on entrepreneurship skills to women beneficiaries. Moreover, $34.9 \%$ of respondents agreed with the statement that UN Women argue that all women beneficiaries were given trainings related to project management. Finally, 100 respondents agreed that the UN Women prepared training related to adequate loan utilization.

From the interview contend that capacity building offered to beneficiaries by UN-Women in Rwanda is held for promoting women's welfare, but since it is done at high level institutions, the beneficiaries have less knowledge on how it is implemented. Results from the present study concur with the findings of Field, et al.(2010). The scholar reiterate that although the government has attempted to advocate for women welfare through women friendly

program, they are not enough for effective women's welfare promotion and awareness. As indicated in Table 4.6 there are significant correlations found between Capacity Building and Women Welfare Promotion in Nyarugenge District. $(\mathrm{r}=00.680, \mathrm{p}=0.04)$, Correlations were statistically significant given that the $\mathrm{p}$ value was $<0.05$ suggesting that an Capacity Building and Women Welfare Promotion in Nyarugenge District has strong positive relation.

\subsection{Conclusion}

The study concludes that awareness campaign was conducted through setting goals, outcomes and timing, stakeholders and target audience, campaign tactics and techniques and building and framing a campaign alliance. For setting goals, outcomes and timing, there is a positive insignificant correlation between setting the goals, outcomes and timing and level of income, and nutrition status. For stakeholders and target audiences, there are positive and significant correlation between stakeholders and target audiences and sales increase. Results on capacity building show that business plan, entrepreneurship skills, project management and adequate loan utilization were undertaken and consequent there are significant correlations found between business plan and income increase, business plan and nutrition. Significant positive correlations were found between project management and nutrition.

To the third objective, the study concludes that agriculture, agribusiness activities, tailoring activities, and outsourced companies in different services were offered to women beneficiaries. In this regard, significant positive correlations were found between agriculture and income, ownership to properties, and agriculture. Significant positive correlations were found between tailoring activities and income level, and ownership to properties and nutrition status.

\subsection{Recommendations}

The Government of Rwanda through the ministry of Justice, Ministry of Gender and Family Promotion, Ministry of foreign affairs and international cooperation, Ministry of Local Government should design and proliferate effective policies tailored towards empowering women to be aware of their rights and duties in the community throughout capacity building. If these policies are fully implemented, improved women's welfare would be enhanced. There is a need to establish women's carrier orientation desks in higher learning institutions for playing a key role in promoting gender between female and male, knowledge and skills on human trafficking and women welfare, reducing structural violence to enhance its awareness in local entities, reduction of poverty, empowering community members and data on equality between men and women towards their rights.

The study proposes that the office of the districts need to scale up in periodical dialogues and campaign to ensure antihuman trafficking were maintained. Adequate and constant monitoring and follow up would be a proactive and preventive strategies for women' welfare promotion strategies. Furthermore, local community leaders should help their citizen in understanding that awareness in fighting human trafficking is key for success and therefore set aside resources for trainings as well as facilitations for good practices. They must inform women and other community members on top of being repeatedly reminded about women rights, community empowerment, and gender equality and sensitivity and initiate cross visits to share experiences women's rights concern-related matters vis-à-vis its awareness.

\subsection{Acknowledgement}

I acknowledge the Almighty God for His abundant Mercy and Grace that gave her health and peace during this research period. My profound gratitude is extended to my lecturers for their support in making this work achievable. I am also grateful to the Management of Mount Kenya University for all the opportunities, knowledge and skills got from the Campus. Special thanks is addressed to Nyarugenge District for allowing me to carry out this study. Lastly, I am grateful to my classmates for their encouragement during the entire university life, and for their significant support. 


\subsection{Reference}

[1].Alvi, M.H.(2016). A manual for selecting sampling techniques in Research. University of Karachi, Iqra University.

[2].Amuzu, C,Jonesm N.\& Perezneto, P.(2010). Gendered risks, Poverty and Vulnerability in Ghana to what extent is the LEAP cash transfer program making a difference? London, ODI (Overseas Development Institute.

[3].Angela, M. (2011). Children Trafficking in Tanzania: Exploring the experiences of trafficked girls in DarSalaam, Tanzania.

[4].Ashraf, N Karlan, D, Yin, W. (2010). Female Empowerment; Impact of commitment product in Philippines, in World Development, 38(3), 333-344.

[5].Asheemwe, F. (2014). Factors pre-disposing women and girls to human trafficking in Rwanda: A baseline survey and needs assessment report, Kigali, Rwanda.

[6].Asika, N. (2010). Research Methodology in Behavioral Sciences. Ikja, Longman. Babbie, E.R. (2009). The practice of social sciences, Wadsworth Pub Co.

[7].Bakary. S. (2012). Sex trafficking, trends, challenges and restrictions of international law.

[8].Baldwin, W. (2011). Creating safe spaces for girl teenage girls; [promoting healthy, security and product to adulthood. Brief No.39. New York, Population.

[9]. Ballington, J. (2012).Empowering women for stronger political parties; a guidebook to promote women's political participation. New York; USA.

[10]. Bandiera, O, Burgess, R,Das, N.C, Gulesci, S., Rausul, I, Shams, R\& Sulaiman, M(2013). Asset Transfer Program for the Ultra poor: A randomized Control Trial Evaluation. Working paper No. 22. BRAC.

[11]. Barkin, J.S \& Cronin, B. (2009). The state and the nation: changing norms and the rules of sovereignty in international relations. Journal of International Organization 48(1) 107-130.

[12]. Beath, A., Chritia, F., Enikolipov, R \& Kabul, S. (2010). Randomized Impact Evaluation of Phase II of Afghanistan's National Solidarity Program (NSP) - Estimates of Interim Program Impact from First Follow-Up Survey. Washington, DC: The World Bank.

[13]. Beijing.at.15.Online.Discussions. (2010, February 1 - 26). Report on Discussions Gender Equality, Peace and Development. Moderated by the Office of the High Commissioner for Human Rights [Blog Post]. Retrieved from:

[14]. http://www.un.org/womenwatch/beijing15/FINAL_Report_OHCHR_Online_discussion_Beijing15.pd f.(accessed March 2019).

[15]. Bifulco, R. (2012). Can Nonexperimental estimates replicate estimates relied on random assignment in evaluations of school choice? A within-study comparison. Journal of Policy Analysis and Management, Vol. 31, No. 3, pp. 729-751.

[16]. Binagwaho, A.(2013) Developing human rights based strategies to increase health care among female sex workers in Rwanda, health and human rights journal, 12(2)1-7.

[17]. Bishumba, N.(2017). GBV prosecutor calls for more punishment. The new times, p1

[18]. Blaxter, L; Hughers,C\& Tight.(2010). How to research, $2^{\text {nd }}$ ed. Open University Press, Celtic Court 22 Ballmoor Buckingham MK18 1XW.

[19]. Booth, D. (2012). Development as collective action issue: addressing the challenges in the context of African countries. London.

[20]. Bruns,G.(2014).Accessing Public Perception: Issues and methods.

[21]. Burnet, JE. (2011). Women have found respect; gender quotas, symbolic representation and female empowerment in Rwanda, 7 politics and Gender (1).303-344.

[22]. Buvinic, M, Fust, N(2014). Promoting women's economic empowering what works? World Bank Policy research working paper, no 7087.

[23]. Carmicjael, S. (2011). Marriage and Power: Age at first marriage and spousal age gap in lesser developed countries. The History of the Family.

[24]. Chawla A, Chakrabarti, S,GhoshG, \& Niwa,M.(2011). Attenuation of years UPR is essential for survival and is mediated by IRE1 Kianse. Journal Article of research support, NIH, Extramural research support, Non-US Government.

[25]. Collingwood,V(2013). Non-governmental organizations, power and legitimacy in international society.

[26]. Cambridge University Press.

[27]. Field, E, Jayachandran, S\& Pande,R.(2010). Do traditional institutions constrain female entrepreneurship/ A field experiment on business training in India, in American Economic Review, 100(2), 125-129.

[28]. Frankish, C.J.(2016). Setting a foundation: underlying values and structures of health promotion in primary health care setting. Primary Health Care Research and Development, 7, 172-182.

[29]. Holmes, R. \& Slater, R. (2012). Social Protection and Gender-a Life-cycle Approach. Australian Agency for International Development (AusAID).

[30]. Hypher, N. (2011). Impact of Cash Transfers on Children. Save the Children, Presentation at ODI lunchtime Seminar.

[31]. IOM. (2010). Diverse Human Trafficking Trends in East African Region Highlights Urgent Need for Greater Protection.

[32]. Johnson, N., Njuki, J., Waithanji, E., Nhambeto, M., Rogers, M. \& Hutchinson Kruger, E. (2013). The Gendered Impacts of Agricultural Asset Transfer Projects: Lessons from the Manica Smallholder Dairy Development Program. 
[33]. Jones, N. \& Holmes, R. (2010). Gender Politics and Social Protection: Why Social Protection is "gender blind". ODI Briefing Paper 62. London, ODI.

[34]. Jones, N. \& Thi V.A.T. (2012). The Politics of Gender and Social Protection in Viet Nam: Opportunities and Challenges. London, ODI.

[35]. Kabeer, N. (2011). Between Affiliation and Autonomy: Navigating Pathways of Women's Empowerment and Gender Justice in Rural Bangladesh. International journal of Development and Change 42(2): 499- 528.

[36]. Kwibuka,E.(2016). Rwanda: MPs hold dialogue on human trafficking. The new times, p.1, Accessed November 2020.

[37]. Mansuri,G and Rao.(2013). Localizing development; Does participation works? World Bank policy review report. Washington DC.USA.

[38]. Materu, M. (2013): Life Expectancy, Schooling and Lifetime Labor Supply: Theory and Evidences Revisited.

[39]. Econometrica, 81(5).

[40]. Oscar,M. (2013). Five Families: Mexican Case Studying (Condor Bodes) Souvenir Press. UK.

[41]. Riza,S.(2010). Women's Collective Mobilization in the Middle East and North Africa. African Journal of Social Sciences. 16(1):9-36.

[42]. Segran, G.(2014). Achieving Gender Equality: Development versus Historical legacies. Economic Studies Tuyizere,P.A (2012). Gender and Development; the Role of Religion and Culture. Fountain Publishers,Uganda. Wafula.O.(2011). Border management and security in Africa. The border institute of Kenya. 